\title{
KEMELIMPAHAN FITOPLANKTON DI PERAIRAN ESTUARI PAYAU BONDAN CILACAP, JAWA TENGAH (The Abundance of Phytoplankton in the Brackish Estuary of Bondan, Cilacap, Central Java)
}

\author{
Tjut Sugandawaty Djohan* dan Annisa Budyasih Ulul Azmi \\ Laboratorium Ekologi dan Konservasi Fakultas Biologi \\ Universitas Gadjah Mada, Yogyakarta 55281.
}

*Penulis korespondensi. Tel: 081392812361. Email: tjutdjohan@ugm.ac.id.

Diterima: 1 Januari 2019

Disetujui: 5 September 2019

\begin{abstract}
Abstrak
Kajian kemelimpahan fitoplankton di perairan estuari payau Bondan Cilacap telah dipelajari. Perairan Bondan merupakan perairan hutan bakau rusak dan dikoloni oleh semak dan liana bakau, padahal daun pohon bakau adalah sumber input nutrien utama untuk komunitas fitoplankton yang merupakan mata rantai pertama dalam jejaring makanan perairan hutan bakau. Pengambilan sampel fitoplankton dilakukan dengan pencuplikan menggunakan modifikasi van Dorn $5 \mathrm{~L}$ dan merupakan komposit $20 \mathrm{~L}$ air dengan ulangan 5 kali. Kualitas perairan yang diukur meliputi kecepatan arus dan angin, suhu air dan udara, kelembaban udara, jeluk perairan dan jeluk Secchi, intensitas cahaya, turbiditas, salinitas, $\mathrm{pH}, \mathrm{NH}_{4}{ }^{+}, \mathrm{NO}_{3}{ }^{-}, \mathrm{PO}_{4}{ }^{3-}$, dan $\mathrm{SO}_{4}{ }^{2-}$. Hasil menunjukkan bahwa cacah spesies dominan adalah fungsional grup diatom, akan tetapi cacah individunya sedikit. Sebaliknya, cacah individu algae koloni melimpah tetapi cacah spesiesnya sedikit, dan terjadi peledakan Aphanocapsa pulchra, 188.260 individu per 100 L. Peledakan ini karena perairan didominasi air tawar dan kerusakan hutan bakau. Peledakan A. pulchra mengindikasikan kualitas perairan hutan bakau Bondan buruk.
\end{abstract}

Kata kunci: Aphanocapsa pulchra, fungsional grup, hutan bakau, fitoplankton, kualitas perairan.

\begin{abstract}
The abundance of phytoplankton in the brackish estuary of Bondan Cilacap have been studied. Bondan waters are setting in the disturbed mangrove ecosystem, which colonized by mangrove shrubs and lianas, whereas, the mangrove leaves are the main source of nutrient input for the phytoplankton community as the first link in the mangrove aquatic food web. Phytoplankton were sampled using a $5 \mathrm{~L}$ modification of van Dorn and a composite of $20 \mathrm{~L}$ of water with 5 replications. The water qualities measured include surface current, wind speed, water and air temperatures, air humidity, Secchi depth and water depth, light intensity, turbidity, salinity, $\mathrm{pH}, \mathrm{NH}_{4}{ }^{+}, \mathrm{NO}_{3}{ }^{-}, \mathrm{PO}_{4}{ }^{3-}$, dan $\mathrm{SO}_{4}{ }^{2-}$. The results showed that the number of the dominant species was diatoms, but the number of the individuals was small. In contrast, the individual number of algae colony was abundant but the species number were few, and Aphanocapsa pulchra was blooming, 188,260 individuals per $100 \mathrm{~L}$. This bloom was due to the waters were dominated by freshwater and the disturbed mangrove trees. The blooming of population of A. pulchra indicated that bad waters quality.
\end{abstract}

Keywords: Aphanocapsa pulchra, functional group, mangrove, phytoplankton, water qualities.

\section{PENDAHULUAN}

Perairan Bondan merupakan perairan hutan bakau rusak dan dikoloni oleh semak dan liana bakau, Acanthus ilicifolius dan Derrys heterophylla (Djohan, 2007; Djohan, 2010). Padahal, daun pohon bakau, misalnya Rhizophora spp, merupakan sumber input hara utama untuk komunitas fitoplankton (Odum, 1971). Fitoplankton berperan sebagai produsen dan makanan bagi konsumen primer zooplankton dan ikan pemakan zooplankton. Kehadiran komunitas fitoplankton diregulasi oleh faktor fisiko-kimia perairan (Syaifullah, 2016). Komunitas fitoplankton tersusun oleh beberapa fungsional grup, antara lain: diatom centric, diatom pennate, algae unicell, algae colony, algae filament, dan dinoflagellate. Oleh sebab itu, kehadiran spesies penyusun fungsional grup komunitas fitoplankton dapat digunakan sebagai indikator kualitas perairan hutan bakau Bondan.

Estuari payau merupakan perairan tempat bercampurnya air sungai dan air laut, dan dipengaruhi oleh pasang dan surut. Ketika pasang perairannya didominasi oleh air laut dan ketika surut didominasi air tawar dari aliran sungai, sehingga salinitas di estuari payau bervariasi (Nybakken dan Bertness, 2005; Djohan, 2010). Nutrien berasal baik dari sungai maupun.

Di estuari hutan bakau, daun pohon bakau berkontribusi besar sebagai input nutrien utama perairan. Daun pohon bakau yang jatuh ke dalam air akan dikoloni oleh bakteri, fungi dan algae, kemudian dimakan oleh detritial feeder. Fesesnya akan dimakan oleh detrital feeder lain sampai 
menjadi produk akhir berupa fine particulate organic matter (FPOM). Selanjutnya FPOM tersebut akan digunakan oleh komunitas fitoplankton sebagai sumber nutrien. Menurut Odum (1971), 95 \% daun pohon bakau masuk ke dalam jejaring makanan detritus. Seperti yang telah dibicarakan sebelumnya, komunitas fitoplankton bergantung pada ketersediaan daun pohon bakau (Bougis, 1976). Akan tetapi, hutan bakau di Segara Anakan telah berubah menjadi semak dan liana bakau, A. ilcifolius dan D. heterophylla (Djohan, 2007).

Tanah timbul yang terbentuk akibat sedimentasi tinggi di Segara Anakan, mempengaruhi pola pasang surut (Sutomo, 1982). Dengan demikian ketika air pasang, maka air sungai akan terjebak. Sedimentasi tinggi dari sungai Citanduy menunjukkan aliran air tawar yang cukup tinggi akan menyebabkan perubahan salinitas perairan hutan bakau Bondan. Rahaman dkk. (2013) melaporkan bahwa salinitas sebagai faktor pembatas dan penentu distribusi komunitas fitoplankton perairan estuari payau. Kehadiran komunitas plankton merespon pada perubahan salinitas tersebut (Djohan, 2010). Berdasarkan uraian tersebut perlu dikaji jenis fungsional grup fitoplankton yang hadir dan kuantitas cacah spesiesnya. Selain itu penting juga untuk diketahui jenis spesies yang dominan dan gambaran kondisi faktor fisiko-kimia yang meregulasi komunitas fitoplankton di perairan hutan bakau Bondan.

\section{METODE PENELITIAN}

\section{Waktu dan Lokasi}

Penelitian dilakukan di perairan Bondan, $07^{0}$ 40' 04.5" S $108^{0}$ 51' 54.2” E, pada bulan Mei 2017. Pengambilan sampel dilakukan pada waktu air pasang Perairan Bondan merupakan perairan ekosistem hutan bakau rusak. Kerusakan hutan bakau disebabkan penebangan pohon bakau dalam skala besar. Di samping itu perairanBondan juga mengalami sedimentasi yang tinggi dari Sungai Citanduy sejak tahun 1980 hingga sekarang. Kali Bondan terletak jauh dari pintu masuk air laut Samudra Hindia. Jeluk perairan Bondan adalah dangkal, 1,35 m. Perairan Bondan didominasi oleh air tawar aliran dari Sungai Citanduy (Gambar 1).

\section{Prosedur}

Pencuplikan sampel plankton dilakukan dengan modifikasi Van Dorn 5 L dan merupakan sampel komposit $20 \mathrm{~L}$ dan dengan ulangan 5 kali. Di setiap titik sampling, sampel air dicuplik dalam kolom air pada jeluk $10 \mathrm{~cm}$ dari permukaan. Air sampel sebanyak $20 \mathrm{~L}$ disaring menggunakan

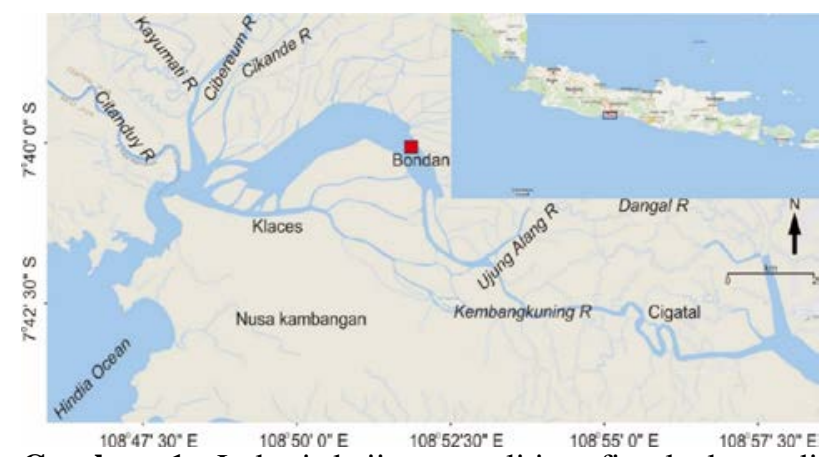

Gambar 1. Lokasi kajian penelitian fitoplankton di perairan Segara Anakan Cilacap 2017.

Wisconsin plankton net. Filtrant plankton disimpan dalam botol flakon 10cc dan difiksasi dengan 4 tetes formalin $4 \%$.

\section{Kualitas Kimia Air, Cacah Spesies dan Individu Fitoplankton}

Analisis kandungan kimia air dilakukan di Balai Laboratorium Kesehatan Yogyakarta. Pengukuran kualitas perairan meliputi $\mathrm{NH}_{4}{ }^{+}, \mathrm{NO}_{3}{ }^{-}$, $\mathrm{PO}_{4}{ }^{3-}, \mathrm{SO}_{4}{ }^{2-}$, dan turbiditas. Analisis kadar $\mathrm{NH}_{4}{ }^{+}$ menggunakan spektrofotometri; kadar $\mathrm{NO}_{3}{ }^{-}$ menggunakan metode Brusin dan diukur dengan spektofotometri; kandungan $\mathrm{PO}_{4}{ }^{3-}$ menggunakan metode Colorimetric, kadar $\mathrm{SO}_{4}{ }^{2-}$, menggunakan metode (APHA. 4500- SO42- E, 2005); sedangkan pengukuran turbiditas menggunakan metode Nephelometric.

Data kualitas fisiko-kimia yang dicuplik meliputi kelembaban udara, intensitas cahaya, kecepatan angin, oksigen terlarut dalam air diukur dengan Metode Micro Winkler, salinitas diukur menggunakan hand-refractometer, dan $\mathrm{pH}$. Cacah spesies dan cacah individu setiap spesies penyusun komunitas phytoplankton dihitung dengan menggunakan SRCC (Sedwigck Rafter Counting Cell) di bawah mikroskop cahaya. Identifikasi spesies phytoplankton menggunakan buku Fresh water biology (Edmonson, 1959), The plankton of South Vietnam: freshwater and marine plankton (Shirota, 1966), dan www.algaebase.org.

\section{Analisis Data}

Data yang diperoleh dari lapangan, dianalisis di Laboratorium Ekologi dan Konservasi Fakultas Biologi UGM. Data yang diperoleh berupa cacah spesies dan cacah individu (densitas) penyusun komunitas fitoplankton, kemudian ditabulasi dan dipilah dalam fungsional grup. Data disajikan dalam bentuk grafik untuk mempelajari kecenderungan densitas cacah individu dan cacah spesies penyusun komunitas fitoplankton di perairan hutan bakau Bondan. Cacah individu species dominan dan fungsional grupnya digunakan sebagai indikator kesehatan perairan hutan bakau. 


\section{HASIL DAN PEMBAHASAN}

\section{Fungsional Grup dan Cacah Spesies}

Fungsional grup komunitas fitoplankton yang hadir di perairan Bondan disusun oleh 6 fungsional grup: diatom centric, diatom pennate, algae unisel, algae koloni, algae filamen dan dinoflagellata. Kehadiran fungsional grup fitoplankton tertinggi adalah diatom pennate 21 spesies per 100 L. Akan tetapi cacah individunya sedikit 1600 individu per 100 L (Gambar 2) dibandingkan dengan algae koloni yang sangat melimpah. Cacah individu fungsional grup algae koloni tersebut adalah 188.813 individu per $100 \mathrm{~L}$. Artinya 118 kali lebih banyak daripada cacah individu diatom, dan funsional grup ini termasuk dalam kelompok cyanobacteria.

\section{Cacah Individu Fitoplankton}

Cacah individu spesies penyusun fungsional grup diatom yang rendah, 300- 1600 individu per 100 L (Gambar 2), menunjukkan bahwa rusaknya hutan bakau menyebabkan sedikitnya input hara dari daun pohon bakau menyebabkan telah mempengaruhi populasi diatom pennate baik maupun centric menjadi sangat sedikit. Seperti yang telah dijelaskan sebelumnya bahwa fungsional grup dominan di perairan bondan adalah algae koloni. Spesies dominan fungsional grup algae koloni adalah A. pulchra dengan densitas 188.260 individu per $100 \mathrm{~L}$ (Gambar 3). Jadi di perairan Bondan terjadi peledakan A. pulchra. Spesies ini adalah fungsional grup algae colony yang tidak disenangi zooplankton dan ikan pemakan plankton karena mempunyai gelatin yang melindungi sel. Gelatin ini tidak disukai oleh predator.
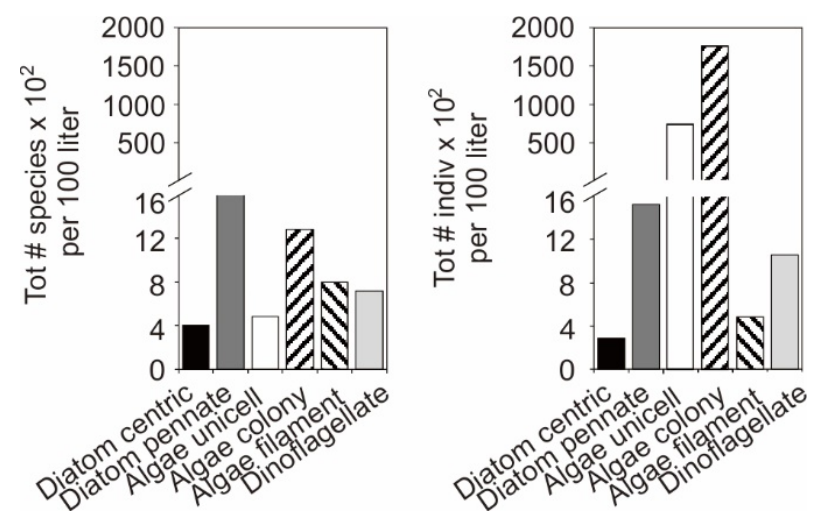

Gambar 2. Total cacah spesies dan cacah individu per fungsional grup penyusun komunitas fitoplankton. Komunitasnya didominasi oleh densitas fungsional grup algae koloni.

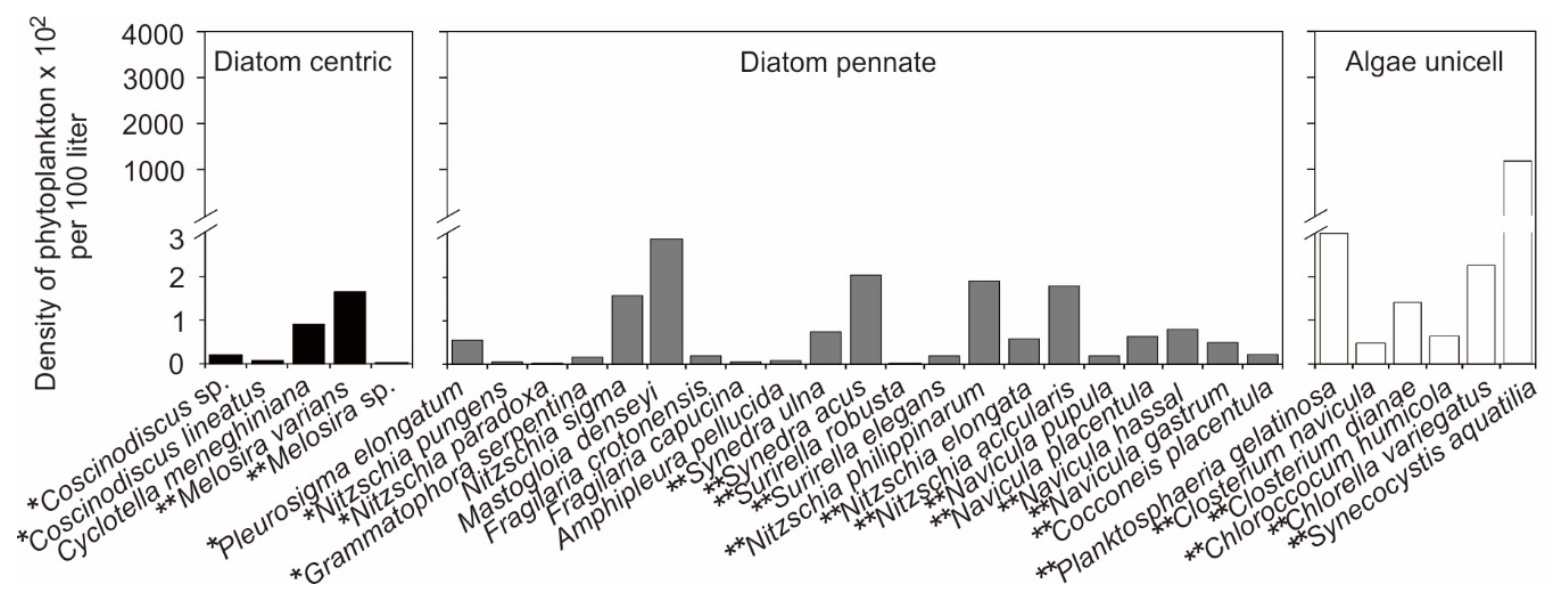

a

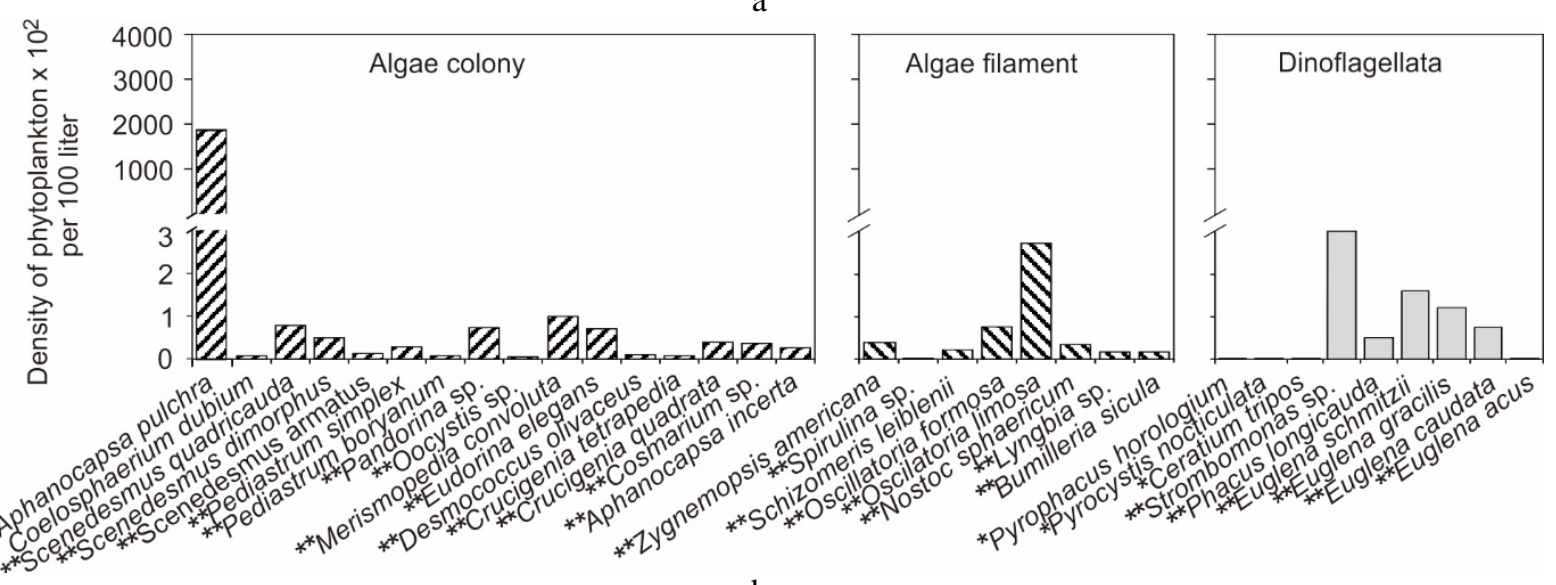

$\mathrm{b}$

Gambar 3 Densitas fitoplankton di dalam fungsional grup (a dan b) di perairan Bondan Mei 2017. 
Aphanocapsa merupakan fitoplankton perairan tawar, dan termasuk dalam kelompok cyanobacteria. Selain itu kehadirannya melimpah karena merespon pada kondisi nutrien dan parameter fisiko-kimia perairan. Pada bulan Mei 2017, perairan Bondan dalam keadaan salinitas sangat rendah, $0 \%$ \% Pencuplikan sampel dilakukan pada waktu air pasang. Salinitas yang rendah mengindikasikan bahwa perairan Bondan dalam kondisi hypohaline. Mengapa ketika pasang input air tawar dari sungai tetap tinggi. Hal ini merupakan pengaruh dari sedimentasi di sebelah selatan Sungai Citanduy, dan akibatnya walaupun pasang perairan Bondan tetap dalam kondisi hypohaline.

Paerl dan Paul (2012) serta O’Neil dkk (2012) menyatakan bahwa observasi lapangan penelitian laboratorium, dan juga pemodelan menunjukkan bahwa kombinasi muatan nutrien antropogenik, peningkatan suhu, peningkatan stratifikasi vertikal, dan peningkatan pasokan $\mathrm{CO}_{2}$ di atmosfer akan mendukung dominasi cyanobacteria di berbagai ekosistem perairan. Cyanobacteria memiliki mekanisme penyerapan $\mathrm{CO}_{2}$ dan hara yang efisien, terlindungi dengan baik dari sinar dan radiasi UV. Mereka sangat mudah beradaptasi dan memungkinkan memanfaatkan perubahan kondisi di lingkungan perairan. A. pulchra juga merupakan kelompok cyanobakteria, perubahan iklim juga telah memperburuk kondisi perairan Bondan, dan ini direspon oleh peledakan populasi tersebut.

Ketersediaan kandungan nutrien di peraian hutan Bondan sedikit. Kadar nitrat dan fosfat sebagai nutrien utama yang digunakan untuk pertumbuhan fitoplankton rendah 0,01 $\mathrm{mg} / \mathrm{L}$ (Gambar 4). Sulfat di perairan 19,74 mg/L, sedangkan turbiditas 38,7 NTU. Kadar nutrien rendah karena daun pohon bakau yang jatuh ke peraian tidak ada. Seperti yang telah dibicarakan sebelumnya, bahwa daun pohon bakau sebagai input utama nutrien di estuari hutan bakau.

Djohan (2007) melaporkan bahwa ekosistem hutan bakau di perairan Segara Anakan rusak parah. Rusaknya ekosistem hutan bakau berarati sedikitnya input nutrien yang berasal dari daun pohon bakau, sehingga nutrien di perairan rendah. Selain itu, nutrien rendah juga dapat disebabkan karena A. pulchra mengambil banyak nutrien yang berasal dari air sungai. sehingga menyebabkan organisme tersebut populasinya meledak.

Shena dkk (2019) juga melaporkan hasil penelitian mereka bahwa peledakan populasi Microcystis secara signifikan mereduksi nitrogen di perairan eutrofik. Mekanisme kuncinya pada setiap lapisan dalam kolum air adalah berbeda. Di dalam kolum air, peledakan Microcystis memfasilitasi pembentukan kondisi anoxic dan memicu denitrifikasi

Denitrifikasi adalah perubahn $\mathrm{NO}_{3}$ menjadi $\mathrm{N}$ bebas. Sebaliknya di perairan Bondan kandungan oksigen terlarutnya tinggi, 9,46 mg/L. Oleh sebab itu di dalam kolum air kandungan $\mathrm{NO}_{3}$, tetap dalam bentuk $\mathrm{NO}_{3}$. Kandungan $\mathrm{NO}_{3}$ relatif rendah, yakni 0,01 mg/L. Hal ini karena ada dua kemungkinan kandungan $\mathrm{NO}_{3}$ habis digunakan oleh A. pulchra atau karena seperti telah dibicarakan sebelumnya yakni input nutrien dari daun pohon bakau sangat sedikit sekali. Perairan Bonda berada di ekosistem hutan bakau rusak. Hutan bakaunya didominasi oleh semak dan liana bakau (Djohan 2007; Djohan 2010). Sebagai ekosistem yang berbasis detritus, daun pohon bakau merupakan pasokan utama nutrient di ekosistem hutan bakau.

Shellner (1993) juga menyatakan bahwa peledakan Mycrocystis sp. di estuari karena perairannya kekurangan oksigen dan konsentrasi nutrien dari sungai yang tinggi. Akan tetapi seperti telah dibicarakan bahwa kadar oksigen terlarut diperairan Bondan 9,46 mg/L (Gambar 4). Artinya perairan dalam kondisi oxic. Tingginya kadar oksigen tersebut juga disebabkan karena agitasi perairan akibat arus $7,3 \mathrm{~m} / \mathrm{s}$ dan kecepatan angin $0,27 \mathrm{~m} / \mathrm{s}$. Pada hal jeluk Secchi nya dangkal 0,6 meter . Keadaan ini menunjukkan bahwa peairan keruh, dan berarti penetrasi cahaya kedalam air juga rendah (Gambar 4). Artinya A. pulchra juga merupakan jenis yang tahan terhadap kekeruhan.

Di samping itu, kondisi perairan sedang mengalami paceklik, ikan dan udang sangat sedikit. Seperti yang telah dibicarakan sebelumnya bahwa fitoplankton yang disukai zooplankton dan ikan planktivorus adalah fungsional grup diatom dan dinoflagellata kecil.

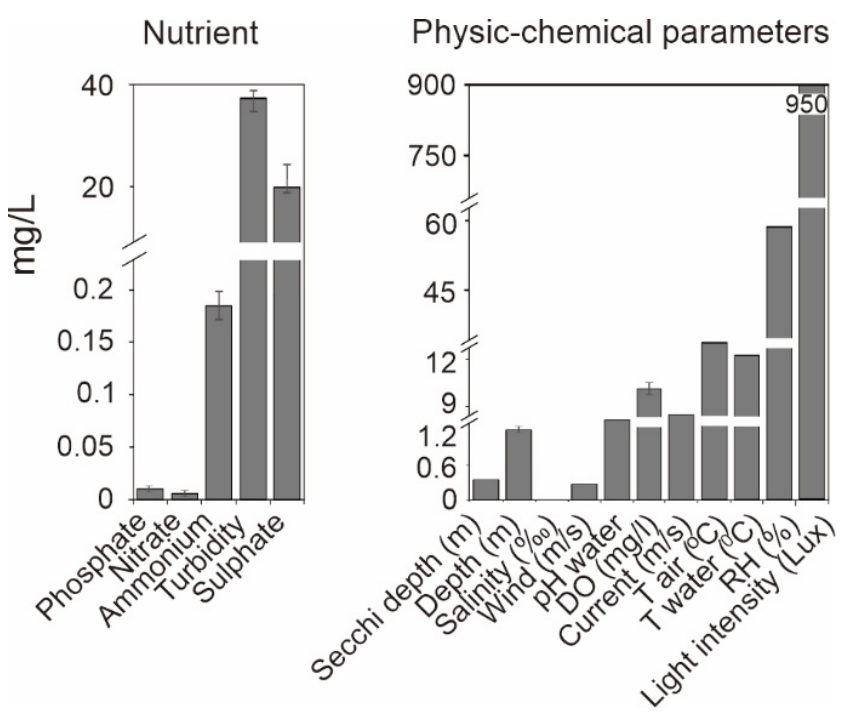

Gambar 4. Kandungan nutrien dan parameter fisikokimia lainnya di perairan Bondan Mei 2017. 
Perairan Bondan didominasi air tawar. Perairan Bondan ketika air tawar dominan maka kehadiran ikan kating (Mystus sp.) yang berasal dari Sungai Citanduy melimpah. Ikan kating memakan zooplankton terutama fungsional grup rotifera. Akan tetapi, Mystus sp. yang ditemukan di perairan Bondan tergolong ikan omnivorus. Hal ini menunjukkan kehadiran fitoplankton dan zooplankton yang sedikit juga karena dimakan oleh Mystus sp.

Chaklader dkk (2014); Mitu dan Alam (2016); serta Rao (2017) melaporkan bahwa Mystus vittatus, $M$. tengara; $M$. bleekeri dan $M$. canvasius tergolong ikan omnivorus. Di saluran pencernaan ikan kating ditemukan paling banyak ikan kecil 46 $\%$, kemudian ikan kating juga memakan crustacean kecil, diatom, blue-green algae, detritus, plant material dan partikel pasir. Feed preference ikan kating juga ditentukan oleh musim. Pada bulan April dan Agustus ikan kating lebih menyukai memakan diatom dan green algae. Sehingga Mystus sp. adalah predator yang dapat memakan baik organisme di dasar maupun perairan permukaan.

\section{KESIMPULAN}

Kehadiran cacah spesies diatom yang lebih tinggi dibandingkan dengan kehadiran fungsional grup lain menunjukkan kondisi perairan dimasa lalu. Rendahnya cacah individu funsional grup diatom menunjukkan bahwa kondisi perairan tidak sehat. Peledakan populasi A. pulchra, algae koloni, di perairan mencerminkan bahwa ekosistem perairan hutan bakau Bondan buruk. Kondisi perairan Bondan memang tidak sehat karena berada di ekosistem hutan bakau rusak, akan tetapi perubahan iklim makin memperburuk keadaan perairan tersebut.

\section{UCAPAN TERIMAKASIH}

Penelitian ini didanai oleh BPPTNBh Fakultas Biologi UGM Tahun Anggaran 2017 No: UGM/BI/1738/UM/05/01. Terimakasih untuk alumnus Fakultas Biologi UGM: Sekar Arum Setyaningrum S.Si, M. Rifqi, SSi., Ryannika, S.Si dan Citra Septiani, S.Si telah membantu mengambil dan mentabulasi data, dan Krisni Suhestiningsih, M.Sc untuk diskusinya yag bernilai, juga untuk teknisi Laboratorium Ekologi dan Konservasi Fakultas Biologi UGM: Bapak Suyono dan Bapak Tukijan yang telah membantu persiapan alat ke lapangan. Terimakasih juga kepada keluarga Mas Dedi, Mas Parmin, dan Pak Nalim Desa Motean, Segara Anakan atas bantuannya selama di lapangan.

\section{DAFTAR PUSTAKA}

Bougis, P. 1976. Marine Plankton Ecology. NorthHolland Publishing Company. Amsterdam..

Chaklader, M. R., A. Nahar., M. A. B. Siddik, and R. Sharker. 2015. Feeding Habits and Diet Composition of Asian Catfish Mystus vittatus (Bloch, 1794) in Shallow Water Of An Impacted Coastal Habitat. World Journal of Fish and Marine Sciences 6:551-556.

Djohan, T. S. 2007. Distribution and Abundance of Mangrove Vegetation in The Disturbed Ecosystem of Segara Anakan, Central Java. J. Manusia dan Lingkungan. 19:94-302.

Djohan, T. S. 2010. Dinamika komunitas plankton di perairan ekosistem hutan bakau Segara Anakan yang sedang berubah. J. Manusia dan Lingkungan 17:135-149.

Edmonson, W. T. 1959. Fresh Water Biology. $2^{\text {nd }}$ ed. John Willey dan Sons, New York.

Mitu, N. R. and M. M. Alam. 2016. Feeding Ecology of a Bagrid Catfish, Mystus tengara (Hamilton, 1822) in the Tanore Wetland of Rajshahi, Northwestern Bangladesh. Journal Applied Ichthyol. 32: 448-455.

Nybakken, J. W., and M. D. Bertness. 2005. Marine Biology: An Ecological Approach. Pearson-Benjamin Cummings, San Francisco.

Odum, E. P. 1971. Fundamental of Ecology. $3^{\text {rd }}$ ed. WB Saunder Company. Philadelphia p 83.

O’Neil, J. M., T.W. Davis, M. Buford, and C. J. Gobler, 2012. The Rise of Harmful Cyanobacteria Blooms : The Potential Roles of Eutrophication and Climate Change. Harmful Algae 14:313-334.

Paerl, H. W. dan V. J. Paul. 2012. Climate Change: Links to Global Expansion of Harmful Cyanobacteria. Water Research 46 (5): 1349136

Rahaman, S. M. B., L. Sarder., M. S. Rahaman., A. K. Ghosh., A. K. Biswas., S. M. S. Siraj., K. A. Huq., A. F. M. Hasanuzzaman., and S. S. Islam. 2013. Nutrient Dynamics in the Sundarbans Mangrove Estuarine System of Bangladesh Under Different Weather and Tidal Cycles. Ecologycal Proceses 2:29.

Rao, K. R. 2017. Food and Feeding Habits Of Freshwater Catfishes (Siluriformes: Bagridae: Mystus sp.). International Journal of LifeSciences Scientific Research 3:786-791.

Sellner, K. G., D. C. Brownlee., M. H. Bundy., S. G. Brownlee, and K. R. Braun. 1993. Zooplankton Grazing in a Potomac River Cyanobacteria Bloom. Estuaries 16:859-872. 
Shirota, A. 1966. The plankton of South Vietnam : freshwater and marine plankton. Over Tech Coorperation Agen, Japan.

Sutomo, H. 1982. Tidal Characteristics And Sedimentology of the Segara Anakan. p. 104105. In E.C.F. Bird, A. Soegiarto, K.A. Soegiarto, and N. Rosengren (eds.). Proceeding of the workshop on coastal resources management in the Cilacap region. The Indonesian Inst. of Sci. and the United Nations University. Jakarta.
Syaifullah, A. S. M., A. H. M. Kamal., M. H. Idris., A. H. Rajaee, and M. K. A. Bhuiyan. 2016. Phytoplankton in Tropical Mangrove Estuaries: Role and Interdependency. Forest Science and Technology. 12:104-113.

Shena, Y., Y. Huanga, J. Hub , P. Lia , Ch. Zhanga, L. Lia , P. Xua , J. Zhang, and X. Chen. 2019. The Nitrogen Reduction in Eutrophic Water Column Driven by Microcystis Blooms. J. Hazardous Materials 385:121578. 